\title{
Efikasi Diri Akademik dan Resiliensi pada Siswa SMA Berasrama di Magelang
}

\author{
Arista Oktaningrum ${ }^{1} \mathcal{E}$ Fauzan Heru Santhoso ${ }^{2}$ \\ Fakultas Psikologi Universitas Gadjah Mada Yogyakarta
}

\begin{abstract}
This study aimed to determine the relationship between academic self efficacy and resiliency of boarding-high school students in Magelang. The hypothesis of this research was that there was positive relationship between academic self efficacy and resiliency. The subjects were ninety (90) 10th grader in X high school located in Magelang. The measuring instruments used were Resilience Scale and Academic Self-efficacy Scale. Simple regression analysis showed that the academic self-efficacy predict resiliency $(R=0.698 ; p=0.001)$. Academic selfefficacy contributed an effect of $48.7 \%$ on the increase of resilience. The conclusion was academic self-efficacy is able to predict resiliency.
\end{abstract}

Keywords: academic self efficacy; boarding-high school students; resilience

\begin{abstract}
Abstrak. Penelitian ini bertujuan untuk mengetahui hubungan antara efikasi diri akademik dan resiliensi pada siswa SMA berasrama di Magelang. Hipotesis pada penelitian ini adalah adanya peran positif antar dua variabel; efikasi diri akademik dan resiliensi. Subjek merupakan 90 siswa kelas 10 di SMA X. Alat ukur yang digunakan adalah Skala Resiliensi dan Skala Efikasi Diri Akademik. Analisis menggunakan teknik analisis regresi sederhana membuktikan hipotesis awal dengan $R=0,698 ; p=0,001$. Efikasi diri memberikan pengaruh sebesar $48,7 \%$ terhadap meningkatnya resiliensi. Disimpulkan bahwa efikasi diri akademik dapat memprediksi resiliensi.
\end{abstract}

Kata kunci: efikasi diri akademik; resiliensi; siswa SMA berasrama

Penerimaan siswa baru pada SMA $X$ dilakukan setiap tahun. Seperti halnya dengan sekolah pada umumnya yang membuka tahun ajaran baru sesuai dengan kurikulum yang ditetapkan oleh pemerintah. Setiap siswa yang mendaftar di SMA X akan melewati beberapa tahapan, seperti TPA, tes psikologi, dan wawancara. Tes psikologi yang diterapkan dalam seleksi ditujukan untuk melihat kondisi psikologis dari siswa. Persyaratan yang diajukan untuk mendaftar di SMA $X$ juga sangat ketat, sehingga SMA $X$ hanya menerima siswa-siswi terbaik.

SMA X merupakan sekolah berbasis asrama yang menerapkan nilai kejuangan, kebangsaan, dan kebudayaan. Nilai-nilai tersebut tidak hanya diterapkan pada peraturan sekolah, namun juga pada sistem pendidikan yang ada. Para siswa yang baru masuk akan ditempa mentalnya sehingga

\footnotetext{
${ }^{1}$ Korespondensi mengenai isi artikel ini dapat dilakukan melalui ristarist@rocketmail.com

2 atau melalui fauzan@ugm.ac.id

E-JOURNAL GAMAJOP
} 
siswa-siswi tersebut akan memiliki mental yang tangguh saat lulus.

Para siswa baru di SMA X pada umumnya belum terbiasa untuk jauh dari orang tua. Terlebih SMA $X$ menerapkan pendidikan semi militer yang berbasis asrama. Hal ini merupakan tekanan yang cukup kuat untuk para siswa yang belum terbiasa dengan pendidikan seperti ini. Perlu adanya penyesuaian diri yang baik dari siswa.

Kemampuan untuk beradaptasi atau menyesuaikan diri dengan lingkungan sangat dibutuhkan oleh siswa. Kemampuan ini dapat membantu siswa untuk berperilaku sesuai dengan keadaan sekitar. Siswa harus terus berkembang dalam beradaptasi dengan lingkungan, sehingga siswa dapat menyesuaikan diri. Penyesuaian diri dan perkembangan siswa akan terasa semakin dibutuhkan saat memasuki dunia yang benar-benar baru yaitu ketika mereka masuk di SMA X.

Ketidakterbiasaan seorang siswa jauh dari orangtua dapat menjadi satu tekanan tersendiri. Namun saat siswa tersebut dapat menghadapi tekanan ini dengan baik, maka siswa akan menjadi pribadi yang lebih tangguh. Kemampuan siswa dalam menghadapi tekanan akan menjadi prestasi tersendiri karena telah mencapai satu babak baru dalam hidup, dengan demikian siswa tersebut akan lebih mampu menghadapi permasala-han berikutnya tanpa bantuan dari keluarga atau orang terdekat.

Tidak hanya lingkungan baru yang akan dihadapi oleh siswa kelas 10 SMA X. Teman-teman baru yang berasal dari berbagai latar belakang pun akan dirasakan pula oleh para siswa. Para siswa memiliki latar belakang budaya dan sosial yang beraneka ragam. Hal ini dikarenakan siswa berasal dari berbagai macam suku bangsa di Indonesia. Keanekaragaman inilah yang merupakan salah satu faktor penentu bagaimana siswa menerima orang baru. Penerimaan terhadap orang lain dapat dilatih dengan sering berhubungan sosial dengan orang dari latar belakang yang berbeda.

Pada awal pembelajaran, siswa akan melewati masa karantina selama 3 bulan. Masa karantina ini akan membuat siswa lebih beradaptasi dengan lingkungan baru. Pihak sekolah tidak memperbolehkan siswa untuk keluar dari sekolah maupun berhubungan dengan dunia luar selama 3 bulan. Termasuk orang tua siswa tidak diperbolehkan menghubungi siswanya selama masa karantina, begitu pun sebaliknya. Masa karantina ini ditujukan untuk melatih siswa bergaul dengan teman asramanya dan melatih mental siswa dalam menghadapi permasalahan saat jauh dari orang terdekat, terutama orang tua. Selama masa karantina, siswa diwajibkan untuk bersekolah seperti biasa dan mengikuti serangkaian kegiatan yang diadakan oleh sekolah.

Selama masa karantina, ada kesulitan lain yang harus dihadapi oleh siswa baru, yaitu tekanan dari senior. Selain pihak sekolah, senior juga membantu siswa baru untuk lebih mematuhi peraturan yang ada. Para senior akan mengajarkan bagaimana cara yang baik untuk menghormati orang tua, cara bergaul dengan teman seangkatan, dan cara menyesuaikan diri dengan lingkungan. Kekerasan secara fisik sangat jarang terjadi di SMA X karena seluruh kegiatan akademik maupun non-akademik berada di bawah pengawasan pamong atau guru SMA $X$. Peneliti telah berbincang dengan beberapa alumni SMA $X$ dan para narasumber mengatakan bahwa tekanan dari senior merupakan salah satu tekanan yang sangat memengaruhi kondisi psikologis mereka.

Proses yang dihadapi siswa dari tahap pendaftaran hingga mulai belajar 
mengajar akan menguras banyak tenaga dan pikiran. Terlebih tekanan-tekanan dari lingkungan baru yang belum pernah ditemui sebelumnya. Para siswa baru membutuhkan daya resiliensi yang baik agar dapat terus bertahan di SMA X.

Data yang didapatkan peneliti dari SMA X menunjukkan bahwa dari tahun 2010 hingga 2016, jumlah siswa yang diterima selalu berbeda dengan siswa yang lulus. Menurut hasil wawancara dengan narasumber, hal ini dikarenakan para siswa yang memilih untuk pindah sekolah. Bukan karena melakukan pelanggaran yang fatal, namun karena para siswa yang pindah merasa tidak mampu menjalani kehidupan di sekolah tersebut. Adapun rincian data siswa yang pindah dalam tabel 1 .

Tabel 1.

Persebaran Kelulusan SMA X lah di bidang sosial akan jauh lebih baik. Berdasarkan penelitian Rustham (2010) pemecahan masalah dalam lingkungan sosial memiliki pengaruh yang signifikan dalam menentukan kecemasan sosial. Ketika individu memiliki kemampuan untuk memecahkan masalah sosial yang baik, maka kecemasan sosialnya akan menurun dan kepercayaan dirinya akan meningkat.

Resiliensi adalah kemampuan individu untuk mengatasi kesulitan dan kembali dalam kondisi yang sama sebelum mengalami kesulitan (Poetry, Ramli, \& Pratiwi, 2012). Siswa yang dapat mengatasi, melalui, dan kembali ke kondisi semula setelah menghadapi masalah adalah siswa yang memiliki daya resilien yang baik. Daya resilien yang baik tidak dapat diraih

\begin{tabular}{ccccccc}
\hline Angkatan & Tahun & Jumlah Siswa & Lulus & Tidak Lulus & Keluar & Pindah \\
\hline XXI & $2010-2013$ & 313 & 301 & - & - & 12 \\
XXII & $2011-2014$ & 317 & 311 & - & - & 6 \\
XXIII & $2012-2015$ & 350 & 341 & - & - & 9 \\
XXIV & $2013-2016$ & 352 & 336 & - & - & 16 \\
\hline
\end{tabular}

Data tersebut menunjukkan bahwa dalam beberapa tahun terakhir, selalu ada siswa yang memilih untuk pindah sekolah. Hal ini biasanya terjadi setelah masa karantina yang diadakan SMA X selama 3 bulan. Siswa yang merasa tidak mampu untuk melanjutkan sekolah di SMA X akan mengundurkan diri dan lebih memilih untuk bersekolah di tempat lain. Kemampuan siswa yang bertahan di SMA X akan terus diuji sampai lulus dari SMA X.

Keberhasilan dalam menghadapi tekanan adalah kemampuan yang sebaiknya dimiliki oleh setiap individu. Dengan begitu, individu akan terus mampu menghadapi masalah-masalah yang lain, serta kemampuannya dalam pemecahan masa- dengan hanya menghadapi satu masalah saja. Kebiasaan siswa untuk menghadapi masalah juga dapat meningkatkan daya resilien mereka. Selain itu, resilien memiliki beberapa faktor penting yang mendukung (Reivich dan Shatte dalam Poetry, dkk. 2012). Faktor-faktor tersebut seperti regulasi emosi, kontrol impuls, optimisme, analisis sebab-akibat, empati, efikasi diri, dan reaching out.

Efikasi diri merupakan kepercayaan diri untuk mencapai tujuan atas dasar usaha diri sendiri (Bandura dalam Baron, et al., 2009). Seorang siswa yang memiliki target untuk mendapat nilai 100 dalam matematika akan memiliki efikasi diri yang baik saat dapat memenuhi targetnya terse- 
but. Persepsi efikasi diri akan sangat membantu dalam mencapai target yang telah ditentukan. Hasil prestasi dan proses yang dijalani individu pun juga akan sesuai dengan persepsi awalnya. Menurut penelitian, terdapat hubungan yang signifikan ketiga hal tersebut, yaitu persepsi individu terhadap efikasi diri, prestasi, dan proses atau performansi individu (Bandura \& Schunk; Norwick; Pajares \& Miller; dalam Azwar, 1996).

Menurut Bandura (Ghufron \& Suminta, 2013) penilaian efikasi diri tidak diukur dari kemampuan diri individu, melainkan dari kepercayaan diri akan apa yang dapat dicapainya. Seorang siswa yang percaya akan kemampuannya untuk mencapai target tertentu pasti akan terus mencoba dan mencoba tanpa mengenal lelah. Usaha dan kepercayaan pada diri sendiri inilah yang merupakan aspek penting dalam efikasi diri. Efikasi diri tidak terlepas dari rasa optimisme terhadap masa depan. Hal ini dikarenakan efikasi diri mengandung komponen keyakinan diri dalam menghadapi masalah di masa depan.

Efikasi diri tidak akan dapat berdiri sendiri. Terdapat variabel lain yang dapat menunjang efikasi diri, seperti lingkungan, perilaku sebelumnya, harapan terhadap hasil, dan variabel kepribadian lainnya. Menurut Kurt Lewin (Suryabrata, 1982) perilaku yang ditunjukkan oleh individu merupakan fungsi dari ruang hidup yang ada di sekitarnya. Jika ruang hidup individu memberikan kesan positif kepada individu, maka individu juga akan menunjukkan perilaku positif dalam kesehariannya. Siswa yang hidup di lingkungan asrama yang memberikan kesan positif, diharapkan juga mempunyai sikap dan perilaku yang positif terhadap kemampuan dirinya, serta perilaku positif kepada warga lingkungan asrama.
Banyak penelitian lain menyebutkan bahwa efikasi diri dapat menjadi tolok ukur produktivitas individu di masa depan (Myers dalam Ghufron \& Suminta, 2013). Jika siswa berasrama sudah memiliki efikasi diri yang baik sejak awal bersekolah (kelas 10) maka produktivitasnya di masa depan, bahkan sampai lulus bisa dipastikan akan semakin membaik. Tidak dapat dipungkiri bahwa siswa yang lebih rajin dan percaya akan kemampuannya, akan memiliki tingkat produktivitas yang jauh lebih baik dibandingkan siswa lainnya.

Walaupun ada siswa yang memilih untuk pindah sebelum lulus, tidak berarti bahwa siswa yang tetap bertahan tidak memiliki masalah dalam psikologisnya. Data SMA X menyatakan bahwa tetap ada siswa yang memiliki permasalahan dalam dirinya dan dalam lingkungan sosialnya. SMA X memiliki sebaran data yang didapat dari tes yang mereka adakan sendiri dan mendapati ada beberapa siswa yang memiliki masalah dalam dirinya dan dalam lingkungan sosial dari taraf ringan hingga berat.

Efikasi diri dan resiliensi merupakan dua hal yang saling mendukung satu sama lain. Penelitian sebelumnya menemukan bahwa terdapat pengaruh positif antara efikasi diri dalam sikap K3 (Kesehatan dan Keselamatan Kerja) sebesar 12,9\% yang secara tidak langsung didapat dari resiliensi (Pradana \& Ismara, 2013). Penelitian ini memiliki subjek siswa kelas XII SMK. Melihat permasalahan sistem pendidikan yang diterapkan SMA X, tekanan yang dihadapi siswa, serta tuntutan untuk berprestasi pada siswa, peneliti ingin mengetahui bagaimana hubungan antara efikasi diri dengan resiliensi siswa kelas 10 SMA $X$ yang berbasis asrama. Jika seorang siswa memiliki efikasi diri yang baik, maka siswa tersebut juga memiliki daya resiliensi yang 
baik pula. Peneliti ingin membuktikan apakah hal ini berlaku untuk siswa yang bersekolah di sekolah berbasis asrama.

Melihat latar belakang tersebut, peneliti menemukan adanya kesenjangan antara resiliensi yang dimiliki siswa kelas 10 SMA $X$ dengan cara yang dilakukan siswa untuk meningkatkan resiliensi. Berdasarkan beberapa penelitian sebelumnya, peneliti menganalisa bahwa efikasi diri merupakan salah satu cara yang baik untuk meningkatkan daya resiliensi siwa. Sehingga peneliti mengajukan hipotesis bahwa ada peran positif efikasi diri akademik siswa kelas 10 SMA X dengan daya resiliensi yang dimiliki siswa.

\section{Metode}

Subjek penelitian pada penelitian ini adalah siswa-siswi kelas 10 di SMA $X$ yang berbasis asrama. Pemilihan subjek siswa berasrama dikarenakan kondisi fisik yang jauh dari orangtua maupun keluarga sehingga kemungkinan untuk mendapat stressor lingkungan lebih tinggi.

Dalam penelitian ini pengumpulan data menggunakan dua skala yaitu Skala Resiliensi dan Skala Efikasi Diri. Skala Resiliensi menggunakan alat ukur milik Ariyani (2012). Ariyani (2012) membuat alat ukur berdasarkan teori milik Reivich dan Shatte (2002) dengan 7 aspek, yaitu regulasi emosi, pengendalian impuls, optimisme, analisis penyebab masalah, empati, efikasi diri, dan reaching out. Skala yang digunakan oleh Ariyani (2012) berjumlah 56 aitem dengan koefisien reliabilitas alpha sebesar 0,959. Koefisien korelasi aitem-aitem tersebut bergerak dari 0,328-0,653.

Skala Efikasi Akademik dimodifikasi dari alat ukur milik Sutanto (2010). Alat ukur milik Sutanto (2010) memiliki nilai cronbach alpha sebesar 0,868 dan koefisien korelasi aitem total bergerak dari 0,274 -
0,691. Dimensi alat ukur diadaptasi dari teori Bandura (1997) yang terdiri atas level, generality, dan strength.

Peneliti memberikan skala kepada para siswa kelas 10 SMA $X$ pada jam mata pelajaran Bimbingan Konseling (BK). Setelah data terkumpul, dilakukan uji hipotesis dengan analisis regresi linier sederhana. Analisis menggunakan aplikasi SPSS versi 16.0.

\section{Hasil}

Hasil analisis regresi linier sederhana menunjukkan nilai $\mathrm{R}$ sebesar 0,698 yang berarti terdapat pengaruh efikasi diri akademik terhadap resiliensi. Selanjutnya terdapat koefisien determinasi $\mathrm{R}^{2}$ sebesar 0,487 yang berarti efikasi diri akademik berperan terhadap resiliensi sebesar $48,7 \%$. Nilai $F$ yang didapat dalam penelitian ini sebesar 83,668 dengan $p<0,001$ yang berarti efikasi diri akademik memiliki pengaruh yang signifikan terhadap resiliensi.

\section{Diskusi}

Hasil penelitian menunjukkan bahwa efikasi diri akademik memiliki peran terhadap resiliensi. Penelitian ini sesuai dengan hasil penelitian Martin \& Marsh (2009) yang mengatakan bahwa resiliensi akademik dapat dicapai dengan 5C, yaitu control, confidence (efikasi diri yang tinggi), coordination (perencanaan yang baik), composure (kecemasan yang rendah), dan commitment (ketekunan yang tinggi). Artikel lain juga menyebutkan bahwa anakanak yang resilien adalah anak-anak yang memiliki empat karakteristik seperti kepekaan indra yang tinggi, memiliki ekspektasi positif yang tinggi, memiliki pemahaman yang baik, dan dapat berkembang sesuai dengan harapan pencapaian, serta rasa humor yang tinggi 
(Breslin dalam Pizzolongo \& Hunter, 2011). Seperti yang dikatakan juga oleh Moynihan, et. al. (2003) efikasi diri adalah usaha individu untuk mencurahkan segala usaha dan akan bertahan dalam mencapai harapan dan menghadapi rintangan.

Efikasi diri merupakan salah satu aspek yang dapat meningkatkan daya resiliensi individu. Hal ini sesuai dengan penelitian Reivich \& Shatte (2002) yang menyebutkan bahwa ada tujuh aspek yang mempengaruhi resiliensi, salah satunya adalah efikasi diri. Penelitian lain juga menyebutkan bahwa resiliensi dan efikasi diri memiliki hubungan yang erat secara empiris (Schwarzer \& Warner, 2013). Selain itu, efikasi diri juga berhubungan positif dengan sikap K3 (Kesehatan dan Keselamatan Kerja) dan hubungan ini didapat secara tidak langsung dari adanya daya resiliensi (Pradana \& Ismara, 2013).

Resiliensi dapat ditingkatkan dengan melakukan keterampilan-keterampilan seperti a). Overcoming. Keterampilan ini bertujuan agar individu tetap dapat termotivasi, produktif, dan ceria walaupun sedang menghadapi masalah. b) Steering through. Komponen penting dalam keterampilan adalah efikasi diri karena individu yang memiliki efikasi diri yang tinggi akan terus mencari jalan keluar dari masalah yang dihadapi. c) Bouncing back. Keterampilan ini juga dapat diartikan sebagai kemampuan individu untuk kembali ke keadaan semula setelah melewati masalah yang ada. d) Resilience is not just reactive. Resiliensi bukan hanya sebagai bentuk reaksi dari suatu peristiwa, namun juga sebagai pola pikir individu untuk dapat melewati masalah. e) Reaching out. Keinginan dan kemampuan individu untuk terus mencari pengalaman baru di lingkungan yang baru pula.

Salah satu keterampilan yang diperlukan untuk meningkatkan resiliensi adalah steering through. Seperti yang sudah dijelaskan, bahwa komponen penting dalam keterampilan tersebut adalah efikasi diri. Tidak hanya dalam hal pencapaian prestasi secara akademik, efikasi diri juga dapat digunakan sebagai keinginan dan kemampuan individu untuk terus mencari jalan keluar dari masalah yang sedang dihadapi. Hal ini berarti individu tidak akan berhenti sebelum mencapai keinginan diri sendiri.

Luthar, et al. (dalam Coleman \& Ganong, 2002) menyebutkan bahwa resiliensi merupakan proses dinamis individu dalam menghadapi kesulitan dan pencapaian adaptasi positif walaupun ada banyak tantangan. Telah disebutkan sebelumnya bahwa efikasi diri akan membuat individu terus mencari solusi lain saat satu solusi tidak memecahkan masalah. Hal ini dapat dikatakan adanya adaptasi positif dari individu untuk menyelesaikan tantangan yang ada.

Efikasi diri merupakan keterampilan individu yang harus dilatih. Pelatihan efikasi diri tersebut dapat dilakukan dengan a) Pencapaian prestasi. Ketika individu berhasil melakukan suatu hal atau mencapai suatu prestasi, maka individu tersebut cenderung ingin mengulang pengalaman yang sama. b) Pengalaman orang lain. Pengalaman positif dari orang lain, terutama yang diidolakan oleh individu, akan lebih mudah untuk memacu individu agar lebih berusaha menggapai cita-cita. c) Persuasi verbal. Motivasi atau nasehat yang diberikan oleh orang lain juga dapat meningkatkan efikasi diri, namun hal ini tidak begitu efektif jika tidak didampingi pelatihan yang lain. d) Kondisi psikologis. Individu akan dengan mudah melakukan efikasi diri jika dapat meminimalisir tekanan yang di dapat dari lingkungan sekitar. 
Salah satu pelatihan yang dapat meningkatkan efikasi diri adalah kondisi psikologis yang baik sehingga dapat meminimalisir tekanan dari luar. Penjelasan ini hampir sama dengan definisi resiliensi milik Masten \& Coatsworth (dalam Kalil, 2003) yang menyebutkan bahwa resiliensi merupakan kemampuan individu untuk tetap dapat produktif walaupun sedang dalam kesulitan atau mendapat tekanan dari lingkungan. Ketika individu dapat meminimalisir tekanan dari luar, maka individu dapat melakukan resiliensi dan efikasi diri.

Penjelasan yang sudah disebutkan lebih memberikan penjelasan akan adanya hubungan yang positif antara efikasi diri dengan resiliensi. Kedua variabel ini memiliki kaitan yang erat satu sama lain. Sehingga tidak dapat dipungkiri bahwa individu yang resilien adalah individu yang dapat melakukan efikasi diri.

\section{Kesimpulan}

Berdasarkan hasil penelitian yang telah dilakukan, maka dapat disimpulkan bahwa resiliensi dan efikasi diri memiliki hubungan positif. Hubungan ini berarti semakin tinggi efikasi diri siswa, maka semakin tinggi pula daya resiliensi siswa.

\section{Saran}

Berdasarkan hasil penelitian yang telah dilakukan, resiliensi dapat ditingkatkan dengan meningkatkan efikasi diri akademik. Dengan demikian, sebaiknya siswa meningkatkan efikasi diri akademik dengan baik. Efikasi diri akademik dapat menjadi tolok ukur prestasi di masa depan. Cara yang efektif untuk meningkatkan efikasi diri adalah dengan menentukan target prestasi yang dapat dicapai oleh siswa. Ketika sudah berhasil melewati satu target, siswa dapat membuat target lainnya yang dirasa lebih sulit sehingga kemampuan siswa juga dapat meningkat.

Penelitian selanjutnya sebaiknya lebih memperhatikan skala yang akan digunakan untuk mengukur resiliensi maupun efikasi diri akademik. Hal ini akan mempengaruhi subjek dalam menjawab setiap aitem yang diberikan. Selain itu, pemilihan waktu dalam pengisian skala juga seharusnya diperhatikan agar subjek tidak terkesan terburu-buru dalam mengisi skala.

\section{Daftar Pustaka}

Ariyani, A. M. (2012). Model bimbingan kelompok berdasarkan pendekatan sistem untuk meningkatkan resiliensi siswa. Semarang: Universitas Negeri Semarang.

Azwar, S. (1996). Efikasi-diri dan prestasi belajar statistika pada mahasiswa. Jurnal Psikologi, 23(1), 33-40. doi: 10.22146/jpsi.10041

Bandura, A. (1997). Self-efficacy: The exercise of control. New York: W. H. Freeman and Company.

Baron, A. R., Branscombe, N. R., \& Donnbyrnt. (2009). Social psychology. New York: Pearson Education.

Coleman, M., \& Ganong, L. (2002). Resilience and families. Family Relations, 51(2) , 101-102. doi: 10.1111/j.1741-3729.2002.00101.x

Ghufron, M. N., \& Suminta, R. R. (2013). Efikasi diri dan hasil belajar matematika: Meta-analisis. Buletin Psikologi , 21(1), 20-30.

Kalil, A. (2003). Family resilience and good child outcomes: A review of the literature. Wellington: Centre for Social Research and Evaluation, Ministry of Social Development. 
Martin, A. J., \& Marsh, H. W. (2009). Academic resilience and academic buoyancy: Multidimensional and hierarchical conceptual framing of causes correlates and cognate CONSTRUCts. Oxford Review of Education, 35(3), 353-370. doi: $\underline{10.1080 / 03054980902934639}$

Moynihan, L. M., Roehling, M. V., LePine, M. A., \& Boswell, W. R. (2003). A longitudinal study of The relationships among job search selfefficacy, job interviews, and employment outcomes. Journal of Business and Psychology, 18(2), 207233. doi: $10.1023 / \mathrm{A}: 1027349115277$

Pizzolongo, P. J., \& Hunter, A. (2011). I am safe and secure: Promoting resilience in young children. $Y C$ Young Children', 66(2) , 67-69.

Poetry, R. V., Ramli, A. H., \& Pratiwi, A. (2012). Resiliensi pada mahasiswa baru penyandang cerebral palsy $(\mathrm{CP})$, Jurnal Psikologi UB , 1-13

Pradana, D., \& Ismara, K. I. (2013). The effect of self efficacy and self-resilience on attitude of occupational health and safety At SMK Muda Patria Kalasan.
Yogyakarta: Fakultas Teknik Universitas Negeri Yogyakarta.

Reivich, K., \& Shatte, A. (2002). The Resilience factor: 7 essential skills for overcoming life's inevitable obstacles. New York: Broadway Books.

Rustham, A. T. (2010). Pengaruh social problem solving dan self esteem terhadap kecemasan sosial pada remaja. Tesis. Yogyakarta: UGM.

Schwarzer, R., \& Warner, L. M. (2013). Perceived self-efficacy and its relationship to resilience. Resilience in Children, Adolescents, and Adults: Translating Research Into Pracatice, 92, 139-150.

Suryabrata, S. (1982). Psikologi kepribadian. Jakarta: PT Raja Grafindo Persada.

Sutanto, P. T. (2010). Hubungan antara kedemokrasian gaya mengajar guru, keotoritatiran pola asuh orang tua serta efikasi diri akademik dengan keterlibatan siswa smp dalam pembelajaran Bahasa Inggris. Tesis. Yogyakarta: Fakultas Psikologi UGM. 